\title{
Pemberdayaan masyarakat dalam pengolahan air Sungai Batanghari menjadi air bersih menggunakan adsorben biochar
}

\author{
Nelson ${ }^{1}$, Helga Dwi Fahyuan ${ }^{2 \star}$, Frastica Deswardani ${ }^{2}$, Nurhidayah ${ }^{2}$, \\ \& M. Ficky Afrianto ${ }^{2}$
}

${ }^{1}$ Program Studi Kimia, Universitas Jambi, Indonesia

${ }^{2}$ Program Studi Fisika, Universitas Jambi, Indonesia

\section{* helgadwifahyuan@unja.ac.id}

\begin{abstract}
Sungai Duren is one of the villages that have the concern of the local government for the provision of clean water because of the difficulty in accessing clean water in the village. The resident does not yet have access to clean water and still very dependent on Batanghari river water. While the turbidity and water quality of the Batanghari river does not have clean water requirements. Based on those facts, it is necessary to assist with counselling and demonstration about simple technology to treat and purify Batanghari river water into drinking water by tools and materials that easily obtained and made. Water filtration technology was easy to make, and then biochar material can be used as an absorbent. Biochar does not experience further weathering, so it would take a long time when it applied as a water filter. The source of biochar was from oil palm empty fruit bunches that not utilized. Some steps that need to be taken so the solution can be realized are first by providing counselling by the socialization of the importance of the availability of clean water for the community and the use of biochar as an adsorbent for water filtration.
\end{abstract}

\begin{abstract}
Abstrak Sungai Duren adalah salah satu desa yang menjadi perhatian pemerintah setempat untuk pengadaan air bersih karena sulitnya akses air bersih di desa tersebut. Penduduk belum memiliki akses air bersih, dan masih sangat bergantung ke air sungai Batanghari untuk memenuhi kebutuhan air sehari-hari. Sedangkan tingkat kekeruhan dan kualitas air sungai Batanghari tidak memenuhi syarat air bersih. Berdasarkan kenyataan di atas maka perlu dilakukan pendampingan melalui penyuluhan dan demonstrasi tentang teknologi sederhana untuk mengolah dan menjernihkan air sungai Batanghari menjadi air minum yang alat dan bahannya mudah diperoleh serta mudah dibuat. Salah satu yang dapat dikembangkan adalah teknologi penyaringan air menggunakan biochar sebagai adsorben. Biochar tidak mengalami pelapukan lanjut sehingga apabila diaplikasikan sebagai penyaringan air akan bertahan lama. Sumber biochar yang digunakan berasal dari tandan kosong kelapa sawit yang sudah tidak termanfaatkan. Beberapa langkah yang perlu dilakukan agar solusi ini dapat terealisasi ialah pertama dengan memberikan penyuluhan berupa sosialisasi pentingnya ketersediaan air bersih bagi masyarakat dan penggunaan biochar sebagai adsorben penyaringan air.
\end{abstract}

Keywords: clean water; biochar; Batanghari river; water purification

\section{○ OPEN ACCESS \\ Citation: Nelson, Fahyuan, H.D., Deswardani, F., Nurhidayah, \& Afrianto, M.F. (2020). Pemberdayaan masyarakat dalam pengolahan air Sungai Batanghari menjadi air bersih menggunakan adsorben biochar. Riau Journal of Empowerment, 3(1), 61-68. \\ https://doi.org/10.31258/raje.3.1.61-68}

Paper type: Community service

Received: 2019-12-19 Revised: 2020-02-10 Accepted: 2020-03-04

Language: Bahasa Indonesia (id)

Funding: Lembaga Penelitian dan Pengabdian kepada Masyarakat Universitas Jambi

ISSN 2623-1549 (online), 2654-4520 (print)

C 2020 Nelson et al. Author(s) retain the copyright of article published in this journal, with first publication rights granted to Riau Journal of Empowerment. The article is licenced under Creative Commons Attribution 4.0 International License. This license permits unrestricted use, distribution, and reproduction in any medium, provided the original author and source are credited. 


\section{PENDAHULUAN}

Sungai Batanghari merupakan sungai terpanjang di pulau Sumatera dengan panjang $800 \mathrm{~km}$ (Saputra, 2009). Mata air sungai Batanghari berasal dari Gunung Rasan yang menjadi hulu dari Sungai Batanghari dan bermuara ke hilir di arah Selat Berhala. Aliran sungai ini melalui beberapa kabupaten yang ada di Provinsi Sumatera Barat dan Jambi, seperti Kabupaten Solok Selatan, Tebo, Batanghari, Kota Jambi, Muaro Jambi, dan Tanjung Jabung Timur sebelum lepas ke perairan timur sumatera dekat dengan daerah Muara Sabak (Tikno, 2000).

Sungai Batanghari memiliki peran besar dalam kehidupan masyarakat bahkan sempat menjadi simbol kejayaan masyarakat Jambi. Sejak dahulu, masyarakat sepanjang Sungai Batanghari telah menggantungkan sebagian besar kehidupan ke sungai Batanghari, mulai dari sektor kehutanan, pertanian, perikanan, dan pemenuhan kebutuhan sehari-hari. Sungai Batanghari juga sangat berperan besar dalam bidang transportasi sebelum adanya jalan darat, tak terkecuali untuk masyarakat Desa Sungai Duren Kecamatan Jambi Luar Kota. Desa Sungai Duren ini merupakan wilayah dataran rendah yang dilalui oleh Daerah Aliran Sungai Batanghari. Dimana di daerah ini selalu terjadi banjir setiap tahunnya. Kondisi alam Sungai Duren yang berawa-rawa dan merupakan dataran rendah mengakibatkan sebagian besar penduduk kesulitan mendapatkan akses air bersih yang memenuhi syarat kesehatan. Masyarakat memanfaatkan air hujan dan air sungai untuk minum, mandi dan cuci. Dari analisis data di lapangan, keadaan ini tampak dengan rendahnya persentase penduduk yang memiliki akses terhadap air bersih yaitu \pm 34 persen. Dari 34 persen tersebut hanya \pm 20 persen yang menggunakan PDAM dan sisanya dari sumur yang airnya keruh dan kecokelatan. Bahkan dari hasil wawancara masyarakat Sungai Duren, air PDAM yang digunakan juga sering berwarna coklat. Keadaan di atas berpotensi meningkatkan penyakit diare dan disentri. Kondisi keadaan air yang di konsumsi warga Desa Sungai Duren dapat dilihat pada Gambar 1.

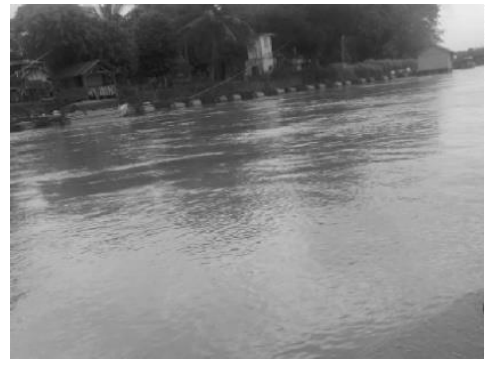

(a)

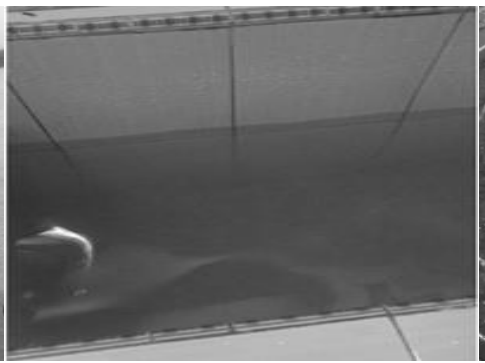

(b)

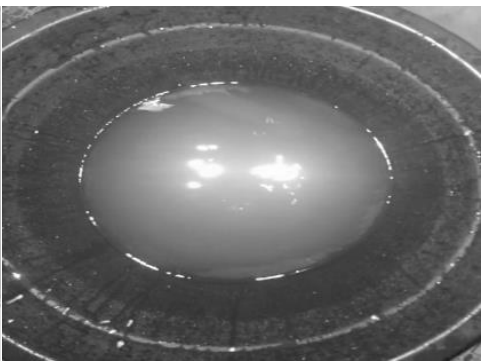

(c)

Gambar 1. Kondisi air yang dikonsumsi warga Sungai Duren (a) air Sungai Batanghari; (b) air PDAM; (c) air sumur warga Sungai Duren

Sungai Duren adalah salah satu desa yang menjadi perhatian pemerintah setempat untuk pengadaan air bersih karena sulitnya akses air bersih di desa tersebut. Penduduk belum memiliki akses air bersih, dan masih sangat bergantung ke air sungai Batanghari untuk memenuhi kebutuhan air sehari-hari. Sedangkan tingkat kekeruhan dan kualitas air sungai Batanghari tidak memenuhi syarat air bersih. Berdasarkan kenyataan di atas maka perlu dilakukan pendampingan melalui penyuluhan dan demonstrasi tentang teknologi sederhana untuk mengolah dan menjernihkan air sungai Batanghari menjadi air minum yang alat dan bahannya mudah diperoleh serta mudah dibuat.

Dari analisis data lapangan, hanya beberapa warga yang sudah melakukan penyaringan sederhana sebelum air sungai tersebut di konsumsi. Meskipun sudah disaring, air masih tetap 
coklat, dengan istilah setempat adalah "air sirup", dengan bau lumpur yang pekat. Berdasarkan keadaan tersebut maka proses penyaringan dengan menggunakan biochar sangat diperlukan. Biochar mirip dengan arang, dari bentuk dan warnanya serta bahan baku pembuatannya. Hanya saja biochar berbeda dengan arang dalam hal fungsi dan proses pembuatannya. Biochar merupakan materi padat yang terbentuk dari karbonisasi biomasa. Biochar mengandung karbon (C) yang tinggi yaitu lebih dari 50\%. Biochar tidak mengalami pelapukan lanjut sehingga apabila diaplikasikan sebagai penyaringan air akan bertahan lama. Biochar juga memiliki kekuatan mekanik dan porositas yang tinngi yang sangat mendukung biochar dijadikan sebagai adsorben. Selain itu, biochar juga efektif menghilangkan logam beracun (Wang et al., 2015; Cui et al., 2016) dan menurunkan polutan organik (Chen et al., 2011; Leng et al., 2015a, 2015b; Fang et al., 2016).

Biochar dapat dibuat dari berbagai bahan organik, seperti serbuk gergaji, sekam padi dan lain-lain. Bahan baku pembuatan biochar umumnya adalah residu biomasa pertanian atau kehutanan, serta bahan organik yang berasal dari sampah kertas, sampah kota dan kotoran hewan (Anonim, 2019). Bila limbah tersebut mengalami pembakaran dalam keadaan Oksigen yang rendah atau tanpa Oksigen akan dihasilkan 3 substansi yaitu Metana dan Hidrogen, biooil, dan arang hayati (biochar) yang mempunyai sifat stabil dan kaya karbon (>50\%).

Pada PPM ini, sumber biochar yang digunakan berasal dari tandan kosong kelapa sawit. Hal ini disebabkan Sungai Duren merupakan daerah perbatasan kota dimana di wilayah tersebut tersebar kebun sawit yang cukup luas, didukung juga oleh tandan kosong dari kelapa sawit tersebut belum terjamah sama sekali. Dengan menerapkan teknologi penyaringan air menggunakan adsorben biochar menggunakan tandan kosong kelapa sawit, hal tersebut akan meningkatkan nilai guna dan ekonomis bahan tersebut.

Untuk dapat mengatasi permasalahan tersebut maka perlu dikembangkan suatu model sistem tepat guna yaitu teknologi penyaringan air menggunakan biochar sebagai adsorben. Adanya sistem ini diharapkan membantu masyarakat Sungai Duren untuk memperoleh air bersih yang layak konsumsi. Kegiatan Program Pengabdian Masyarakat (PPM) ini ditargetkan dapat membantu mitra dalam memanfaatkan bahan alam yaitu tandan kosong kelapa sawit sebagai biochar dalam sistem penjernihan air sehingga masyarakat Desa Sungai Duren dapat mengkonsumsi air bersih sesuai standar kesehatan dan meningkatkan taraf dan ekonomi masyarakat.

\section{METODE PENERAPAN}

Kegiatan ini dilaksanakan di Univeristas Jambi dan Desa Sungai Duren, Kecamatan Jambi Luar Kota, selama 4 bulan dari Juni s/d September 2019. Tahapan awal yaitu tahap pembuatan penyaringan air dan tahapan pengujian alat saringan air dilakukan di Universitas Jambi. Setelah sistem berhasil dibuat, kemudian kegiatan dilanjutkan ke tahapan sosialisasi ke masyarakat. Pada tahapan terakhir diikuti oleh masyarakat desa Sungai Duren terutama penduduk yang memiliki sumber air yang kurang bersih untuk memenuhi kebutuhan seharihari.

Tahapan kegiatan pertama yaitu tahapan pembuatan penyaringan air dimana pada tahap ini dilakukan perancangan sistem pengolahan air dengan penyaring berganda. Desain sistem pengolahan air dengan penyaring-berganda ditunjukkan pada Gambar 2. Sistem terdiri atas sederet kerikil, zeolite, pasir dan biochar. Sistem pengolahan air ini dibuat dengan menderetkan empat buah pipa paralon yang dijadikan sebagai tabung untuk bahan dasar penyaringan air. 
Tahap berikutnya dilanjutkan dengan pengujian alat saringan air. Pada tahap ini system pengolahan air yang telah dibuat kemudian diuji dengan mengalirkan air yang keruh (tidak bersih) ke dalam tabung. Pertama-tama air dialirkan dalam tabung yang berisi biochar yang selanjutnya diteruskan ke tabung berisi pasir, kemudian ke tabung berisi ziolit dan terakhir ke tabung berisi kerikil. Sistem dianggap mampu menjadi alat penyaringan air saat air yang keluar dari tabung terakhir berupa air yang jernih. Kejernihan air ini dapat dilihat dengan membandingkan air yang berisi air hasil saringan dengan air sebelum disaring.

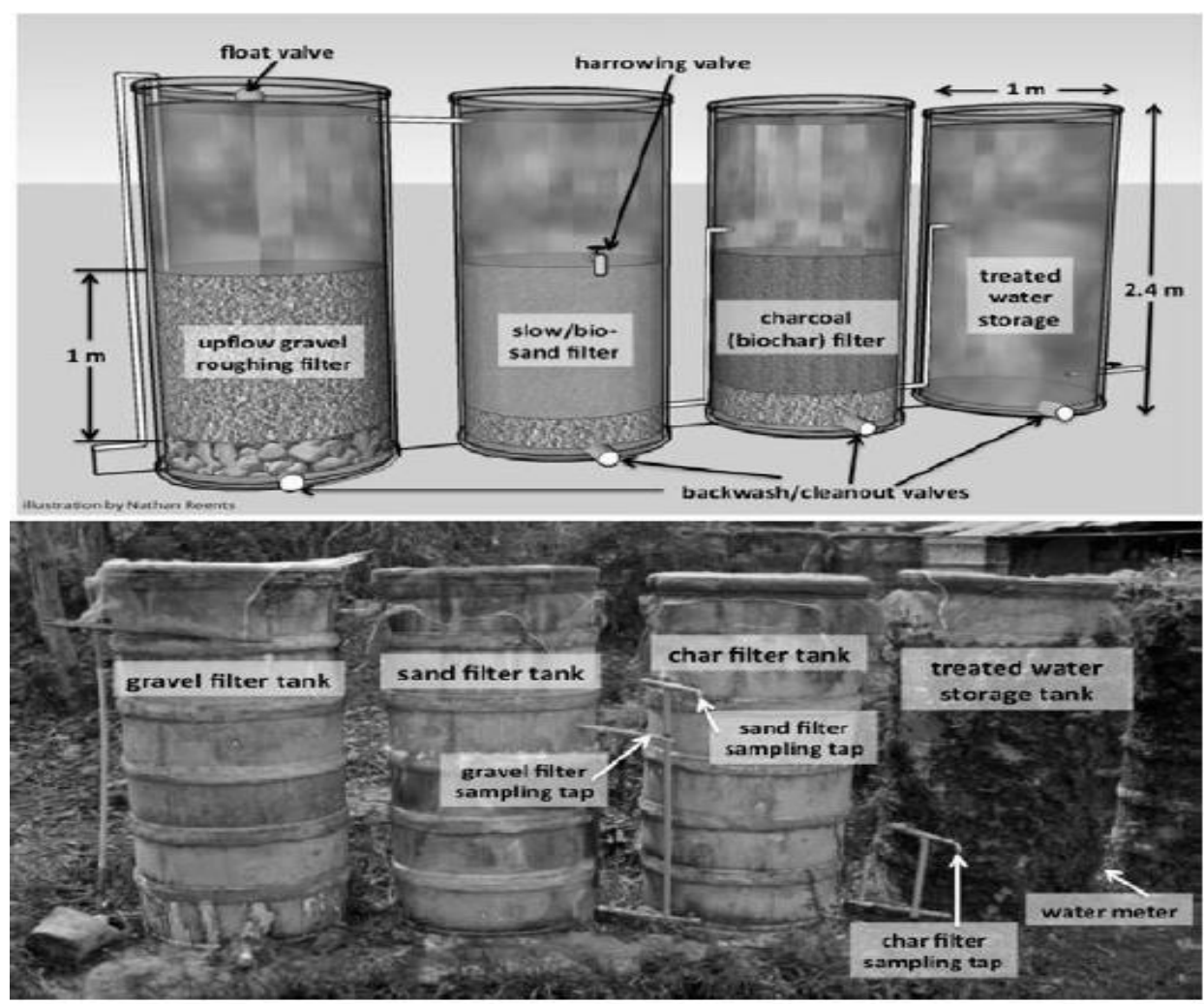

Gambar 2. Sistem pengolahan air dengan penyaring berganda (Kearns, 2013)

Tahapan akhir ialah berupa sosialisasi sistem pengolahan air ke masyarakat. Banyaknya peserta yang ikut dalam kegiatan PPM ini \pm 45 peserta. Pada kegiatan sosialisasi ini mayarakat diberikan wawasan pentingnya ketersediaan air bersih bagi masyarakat dan penggunaan biochar sebagai adsorben penyaringan air sungai. Selanjutnya, pemberian wawasan mengenai teknik pembuatan biochar dari tandan kosong kelapa sawit, pengoperasian dan perawatan sistem pengolahan air dengan penyaring-berganda. Diharapkan dengan beberapa tahapan di atas dapat menjadikan masyarakat lebih paham akan pemanfaatan bahan alam seperti tandan kosong kelapa sawit sebagai biochar. Penggunaan biochar sebagai adsorben ini diharapkan dapat dipraktekkan oleh masyarakat untuk pemenuhan kebutuhan air dalam kehidupan seharihari.

\section{HASIL DAN KETERCAPAIAN SASARAN}

\section{Tahap Pembuatan Penyaringan Air}

Pelaksanaan pembuatan alat penyaringan air berbahan dasar biochar dilaksanakan secara bertahap. Tahap pertama yaitu melakukan survey lokasi air yang digunakan masyarakat Desa 
Sungai Duren. Survey dilakukan dengan melihat bentuk pengolahan air yang sudah dilakukan masyarakat. Kenyataan di lapangan masih banyak warga yang mengkonsumsi air sungai secara langsung tanpa dilakukan penyaringan.

Berdasarkan tahap pertama yang telah dilaksanakan, penulis menambahkan gagasan untuk membuat sebuah alat penyaringan air yang berbahan dasar biochar dari tandan kosong kelapa sawit. Penggunaan tandan kosong kelapa sawit ini terinspirasi dari banyaknya sawit di pemukiman warga tersebut, dimana tandannya tidak terolah dan membusuk sehingga memberikan aroma tidak sedap ke pemukiman warga.

Biochar dapat diperoleh dari pembakaran biomassa dengan kondisi minim oksigen, dapat dilakukan dengan pembakaran konvensional dengan menggali tanah dan memasukkan drum ke dalamnya, dimana di dalam drum terlebih dahulu diisi dengan sumber biomassa yang akan digunakan. Hasil dari pembakaran biomassa tersebut berupa residu padat yang terbentuk dari karbonisasi biomasa yang kaya akan unsur karbon (C) yaitu lebih dari 50\%. Biochar tidak mengalami pelapukan lanjut sehingga apabila diaplikasikan sebagai penyaringan air akan bertahan lama, Biochar juga memiliki kekuatan mekanik dan porositas yang tinggi yang sangat mendukung biochar dijadikan sebagai adsorben.

Pada kegiatan PPM ini, proses pembuatan biochar dilakukan dengan pembakaran menggunakan tungku tertutup dengan kondisi minim oksigen dimana sumber panas yang digunakan dari gas LPG. Pembakaran dilakukan selama 3 jam, proses pembuatan dan hasil dari pembakaran tersebut seperti yang terlihat pada Gambar 3 dan 4.
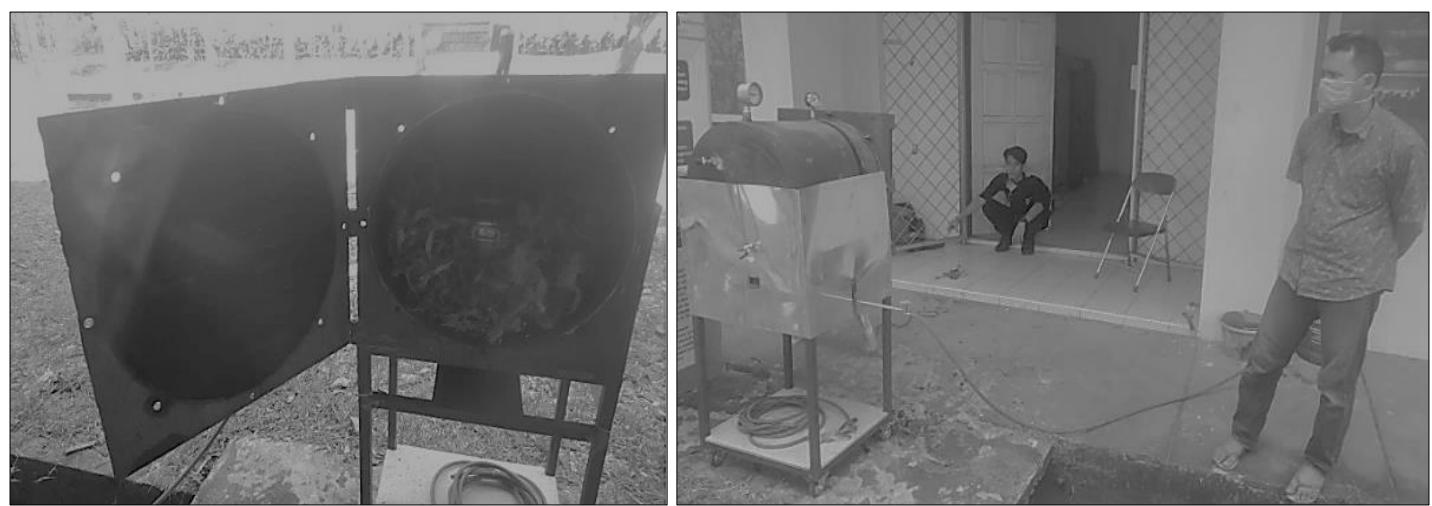

Gambar 3. Proses pembakaran tandan kosong kelapa sawit

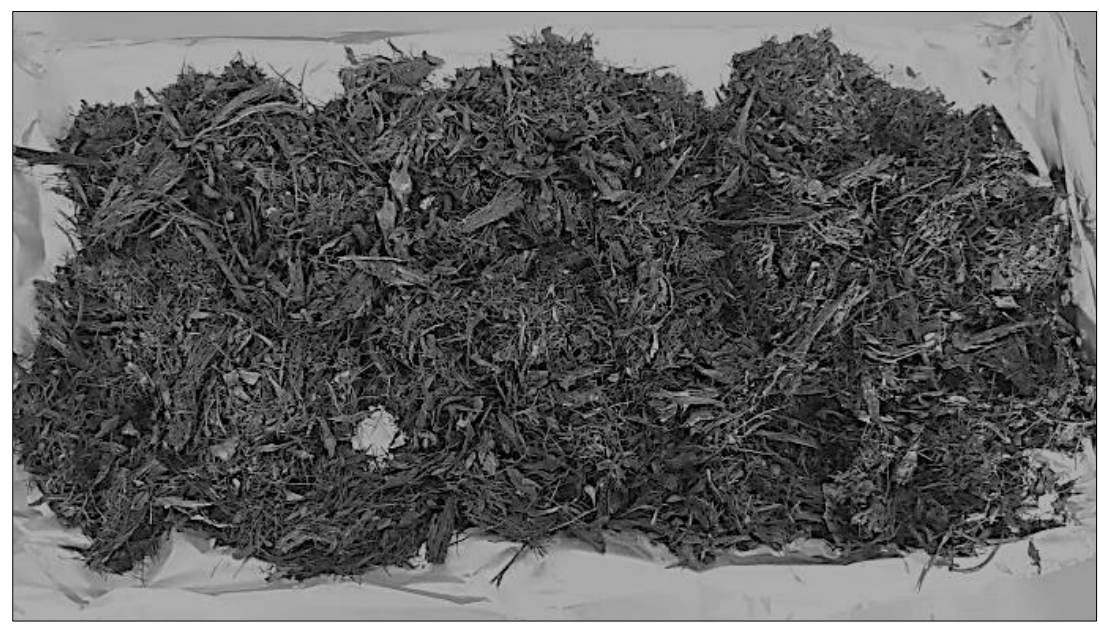

Gambar 4. Biochar hasil pembakaran tandan kosong kelapa sawit 
Setelah selesai pembuatan biochar dilanjutkan ke tahap pembuatan alat saringannya dengan mengaplikasikan teknik penyaringan berganda dengan menderetkan empat buah pipa paralon yang dijadikan sebagai tabung untuk bahan dasar penyaringan air. Empat tabung tersebut akan di isi dengan kerikil, zeolite, pasir dan biochar, seperti yang terlihat pada Gambar 5.

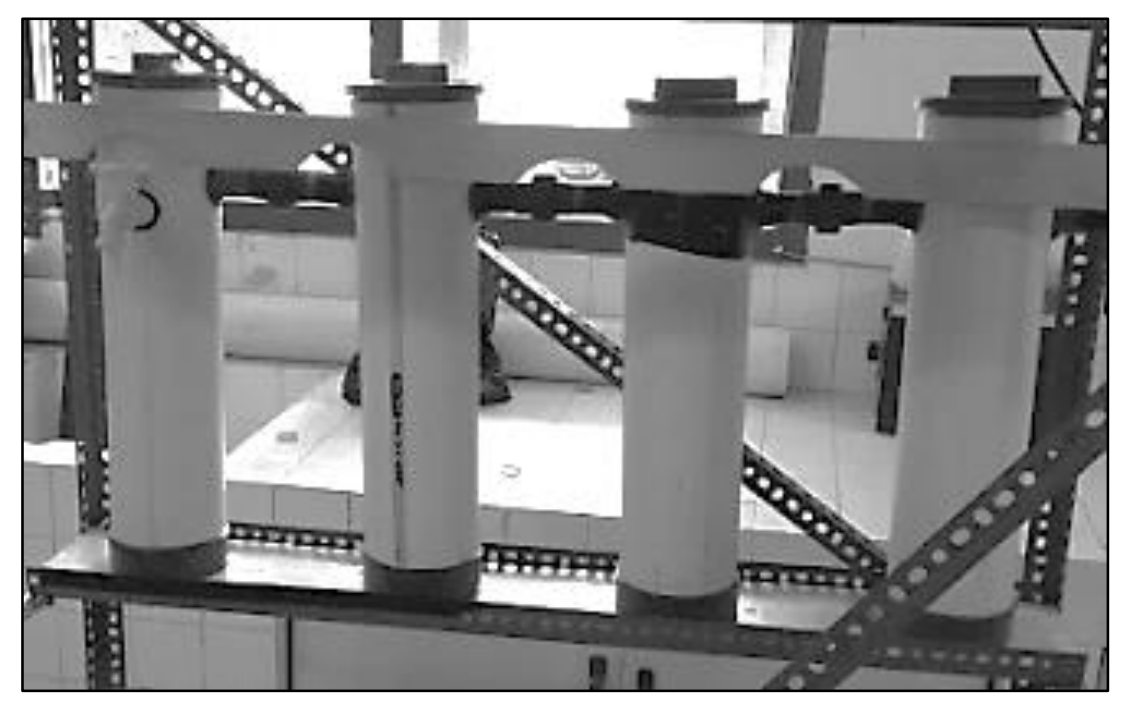

Gambar 5. Desain tabung penyaringan air

\section{Tahap Pengujian Alat Saringan Air}

Pengujian alat dilaksanakan 1 bulan sebelum dilaksanakan sosialisasi kepada masyarakat. pengujian dilaksanakan tepatnya pada tanggal 30 Juli 2019 bertempat di laboratorium Fakultas Sains dan Teknologi Universitas Jambi, seperti yang terlihat pada Gambar 6.

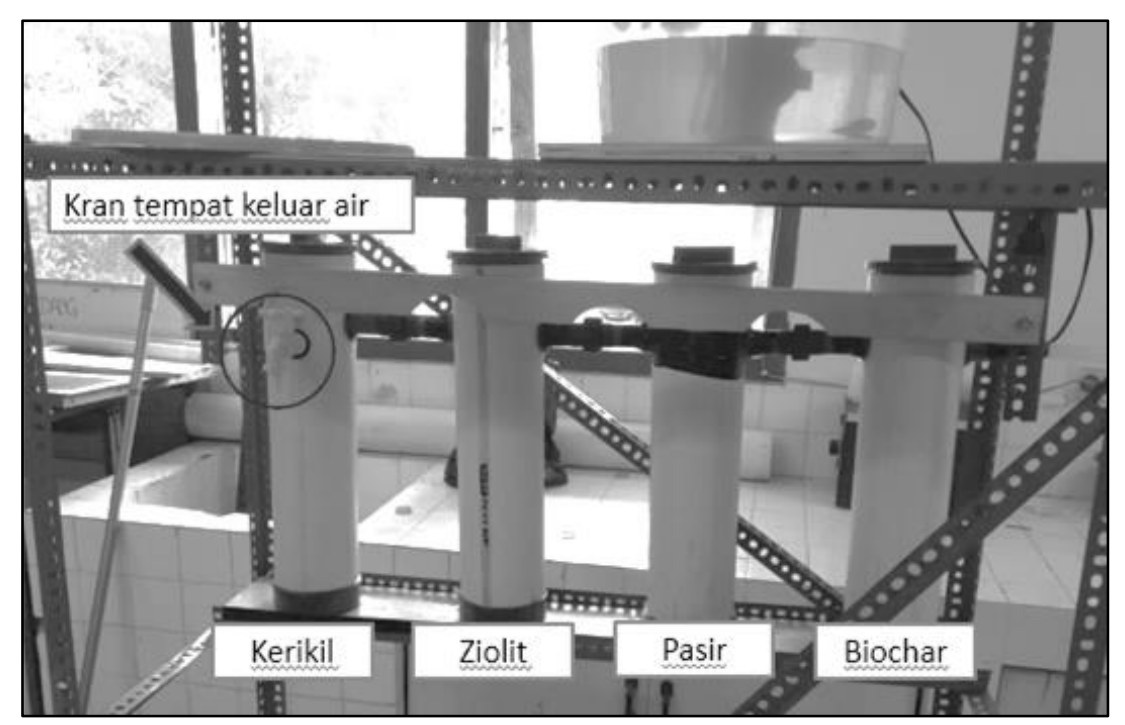

Gambar 6. Pengujian alat penyaringan air

Alat penyaringan air yang dibuat merupakan teknik dari penyaringan berganda. Tahap pertama air yang keruh di aliri ke tabung yang berisi biochar tandan kosong kelapa sawit, pada tahap ini terjadi proses absorbansi senyawa-senyawa organik oleh biochar, penyerapan ini sangat didukung oleh tingginya porositas yang dimuliki biochar. Selain menyerap senyarap senyawa organik, biochar juga mampu mengikat logam-logam berat yang terkandung di air. Tahap selanjutnya air dialiri ke tabung yang berisi pasir, zeolit dan kerikil, dan air bersih hasil 
penyaringan dikeluarkan melalui kran. Hasil uji penyaringan air ini menunjukkan perubahan air yang terlihat lebih jernih dibandingkan air sebelum disaring. Perbandingan tersebut dapat dilihat pada Gambar 7.

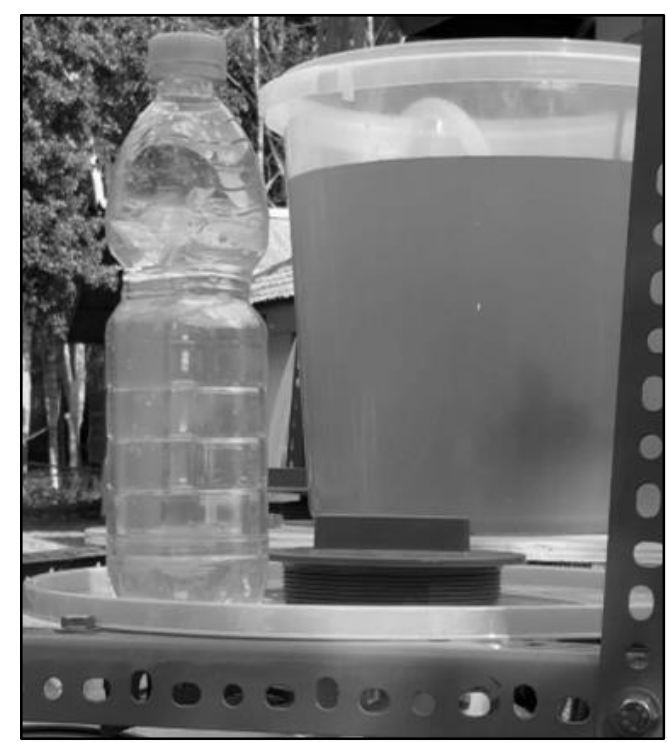

Gambar 7. Perbandingan air sebelum dan setelah disaring

\section{Tahap Soliasisasi ke Masyarakat}

Penulis mengunjungi masyarakat Desa Sungai Duren dalam rangka memberikan penyuluhan berupa sosialisasi pentingnya ketersediaan air bersih bagi masyarakat dan penggunaan biochar sebagai adsorben dalam penyaringan air. Selanjutnya pemberian wawasan mengenai gambaran teknik pembuatan biochar dari tandan kosong kelapa sawit dan gambaran cara pembuatan, pengoperasian dan perawatan sistem pengolahan air dengan penyaring berganda. Kegiatan sosialisasi tersebut telah dilaksanakan pada Sabtu, 31 Agustus 2019, yang dihadiri sekitar 75\% masyarakat dari RT Desa Sungai Duren. Selama pelaksanaan sosialisasi, masyarakat sangat antusias yang ditunjukkan dengan aktifnya masyarakat dalam diskusi tanya jawab. Pelaksanaan kegiatan ditunjukkan pada Gambar 8.

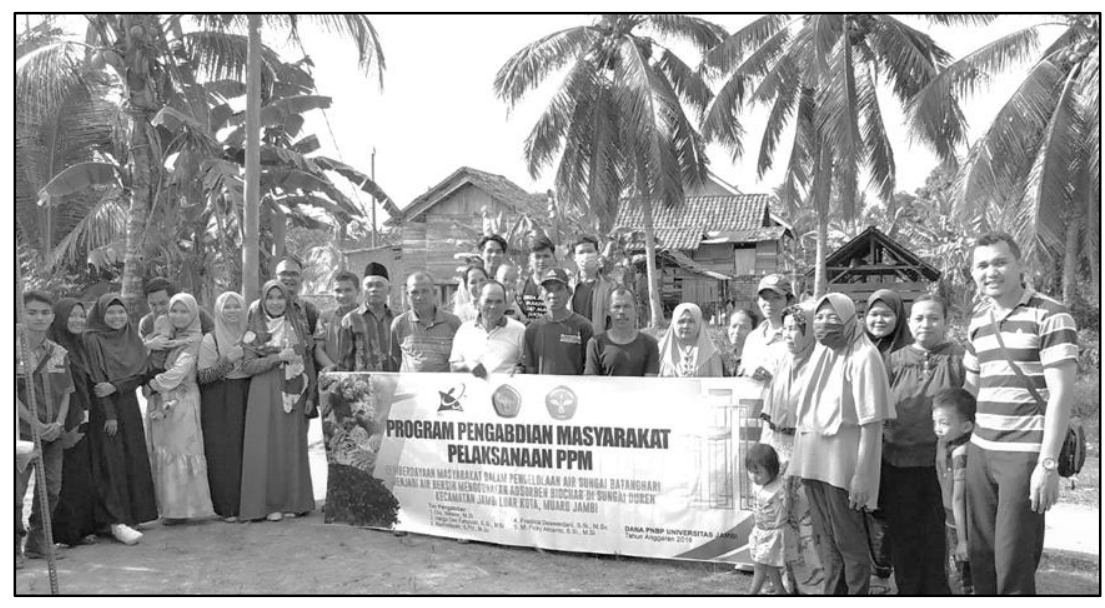

Gambar 8. Kegiatan sosialisasi sistem pengolahan air dengan penyaring berganda dan manfaat biochar sebagai adsorben 


\section{KESIMPULAN}

Kegiatan pengabdian kepada masyarakat yang berjudul Pemberdayaan Masyarakat dalam Pengolahan Air Sungai Batanghari Menjadi Air Bersih Menggunakan Absorben Biochar di Desa Sungai Duren Kecamatan Jambi Luar Kota telah terlaksana. Masyarakat menunjukkan sikap antusias selama proses sosialisasi dan aktif dalam sesi diskusi. Alat penyaring air yang berupa sistem penyaring berganda memiliki kemampuan yang baik dalam menjernihkan air sehingga masyarakat dapat menerapkan alat ini untuk menjernihkan air sebelum digunakan dalam kehidupan sehari-hari.

\section{UCAPAN TERIMA KASIH}

Terimakasih kepada Lembaga Penelitian dan Pengabdian kepada Masyarakat Universitas Jambi yang telah memberikan dana untuk jalannya pengabdian ini.

\section{Daftar Pustaka}

1. Anonim. (2019, March 25). Pengertian SAE. Retrieved from http://bambangtresnow.blogspot.com/2012/01/pengertian-sae.html

2. Chen, B., Chen, Z., \& Lv, S. (2011). A novel magnetic biochar efficiently sorbs organic pollutants and phosphate. Bioresource Technology, 102(2), 716-23. https://doi.org/10.1016/j.biortech.2010.08.067

3. Cui, X., Fang, S., Yao, Y., Li, T., Ni, Q., Yang, X., \& He, Z. (2016). Potential mechanisms of cadmium removal from aqueous solution by Canna indica derived biochar. Science of The Total Environment, 562, 517-525. https://doi.org/10.1016/j.scitotenv.2016.03.248

4. Fang, W., Wang, Q., Han, D., Liu, P., Huang, B., Yan, D., et al. (2016). The effects and mode of action of biochar on the degradation of methyl isothiocyanate in soil. Science of The Total Environment, 565, 339-345. https://doi.org/10.1016/j.scitotenv.2016.04.166

5. Kearns, J. (2013). Desentralisasi Pengolahan Air Lestari dengan Menggunakan Adsorben Biochar Lokal bagi Komunitas Pedesaan yang Sedang Berkembang. Echo Asia Notes, 2013(17), 1-17.

6. Leng L, Yuan X, Huang H, Shao, J., Wang, H., Chen, X., et al. (2015a). Bio-char derived from sewage sludge by liquefaction: Characterization and application for dye adsorption. Applied Surface Science, 346, 223-231. https://doi.org/10.1016/j.apsusc.2015.04.014

7. Leng, L., Yuan, X., Huang, H., Wang, H., Wu, Z., Fu, L., et al., (2015b). Characterization and application of bio-chars from liquefaction of microalgae, lignocellulosic biomass and sewagesludge. Fuel Process Technology, 129, 8-14. https://doi.org/10.1016/j.fuproc.2014.08.016

8. Saputra, F.M. (2009). Daerah Aliran Sungai (DAS) Batanghari. Jakarta, Indonesia: Jurusan Geografi, Fakultas MIPA, Universitas Indonesia.

9. Tikno, S. (2000). Analisis Debit di Daerah Aliran Sungai Batanghari. Jurnal Sains Teknologi Modifikasi Cuaca, 1(1), 101-8. https://doi.org/10.29122/jstmc.v1i1.2111

10. Wang, S., Wang, K., Dai, C., Shi, H., \& Li, J. (2015). Adsorption of Pb2+ on aminofunctionalized core-shell magnetic mesoporous SBA-15 silica composite. Chemical Engineering Journal, 262, 897903. https://doi.org/10.1016/j.cej.2014.10.035 